\title{
Synthesis and in vivo evaluation of non-hepatotoxic acetaminophen analogs
}

\author{
Anthony L. Vaccarino, ${ }^{\mathrm{a}, \mathrm{c}, \dagger}$ Dennis Paul,,${ }^{\mathrm{a}, \mathrm{b}, \dagger}$ Pranab K. Mukherjee, ${ }^{\mathrm{a}}$ \\ Elena B. Rodríguez de Turco, ${ }^{a}$ Victor L. Marcheselli, ${ }^{\mathrm{a}}$ Liang Xu, ${ }^{\mathrm{d}}$ \\ Mark L. Trudell, ${ }^{\mathrm{d}}$ J. M. Minguez, ${ }^{\mathrm{e}}$ M. P. Matía,${ }^{\mathrm{e}}$ Carlos Sunkel, \\ Julio Alvarez-Builla ${ }^{\mathrm{e}}$ and Nicolas G. Bazan ${ }^{\mathrm{a}, *}$ \\ ${ }^{a}$ Neuroscience Center of Excellence, Louisiana State University Health Sciences Center, New Orleans, LA 70112, USA \\ ${ }^{\mathrm{b}}$ Department of Pharmacology, Louisiana State University Health Sciences Center, New Orleans, LA 70112, USA \\ ${ }^{\mathrm{c}}$ Department of Psychology, University of New Orleans, LA 70148, USA \\ ${ }^{\mathrm{d}}$ Department of Chemistry, University of New Orleans, LA 70148, USA \\ e Departamento de Química Orgánica, Universidad de Alcalá, 28871 Alcalá de Henares, Spain
}

Received 22 August 2005; revised 17 July 2006; accepted 26 July 2006

Available online 21 August 2006

\begin{abstract}
A series of acetaminophen (APAP) analogs, 2-(1,1-dioxido-3-oxo-1,2-benzisothiazol-2(3H)-yl)- $N$-(4-hydroxyphenyl)alkanecarboxamides, bearing a heterocyclic moiety linked to the $p$-acylaminophenol fragment, were prepared in a general project to develop APAP analogs with modulated pharmacokinetic profiles. Unexpectedly, the products described maintained the in vivo analgesic profile, while the characteristic hepatotoxicity of APAP was consistently reduced. One of the products, 5a, was studied in vivo in comparison with APAP. Compound 5a displayed an analgesic efficacy comparable to that of APAP. A relatively high acute oral dose of $5 \mathbf{a}(6 \mathrm{mmol} / \mathrm{kg})$ produced no measurable toxicity, whereas the equimolar dose of APAP increased transaminase activity, depleted hepatic and renal glutathione, and resulted in mortality. In human hepatocytes (HEPG-2) and in human primary cultures of normal liver cells, APAP, but not 5a, was associated with apoptotic cell death, Fas-ligand up-regulation, and CAR (constitutive androstane receptor) activation, contributing to a favorable safety profile of 5a as an orally delivered analgesic.
\end{abstract}

(c) 2006 Elsevier Ltd. All rights reserved.

\section{Introduction}

Because of the relatively low incidence of gastrointestinal and hypersensitivity reactions at normal therapeutic doses, acetaminophen (APAP, Fig. 1) is considered to be the drug of choice for mild to moderate pain that is not caused by inflammation. ${ }^{1}$ Despite its widespread use, the mechanisms that mediate the analgesic and antipyretic effects of APAP are not entirely understood. Although in vitro studies have demonstrated an ability of APAP to inhibit cyclooxygenase- 1 and $-2(\mathrm{COX}-1$ and -2$),{ }^{2,3}$ its weak anti-inflammatory activity as compared with that of non-steroidal anti-inflammatory drugs (NSA-

Keywords: Acetaminophen; Hepatotoxicity; Analgesic; Glutathione; Fas ligand constitutive androstane receptor.

* Corresponding author. Tel.: +1 504599 0831; fax: +1 504568

5801; e-mail: nbazan@1suhsc.edu

$\dagger$ These authors contributed equally to this work.
IDs) suggests that other non-COX-related mechanisms also are involved. ${ }^{4-6}$ More recently, the pharmacological effects of APAP have been suggested to be related to the formation of a metabolite (AM404, Fig. 1) that interferes with targets involved in pain and thermoregulation, including COX-mediated prostaglandin synthesis, and vanilloid and cannabinoid receptor systems. ${ }^{7}$

Although APAP shows low incidence of gastrointestinal and other COX-related adverse effects as compared with most NSAIDs, it is well established that APAP can cause hepatotoxicity ${ }^{8}$ and nephrotoxicity. These effects can potentially be lethal,,, 10 particularly after ingestion of large doses or after chronic use of small doses when liver function is already compromised (e.g., in the elderly and in patients with alcoholic liver disease). Although it is likely that multiple pathways lead to APAP-induced hepatotoxicity, ${ }^{11}$ oxidation of APAP to the corresponding $N$-acetyl- $p$-benzoquinone imine (NAPQI) is likely a 

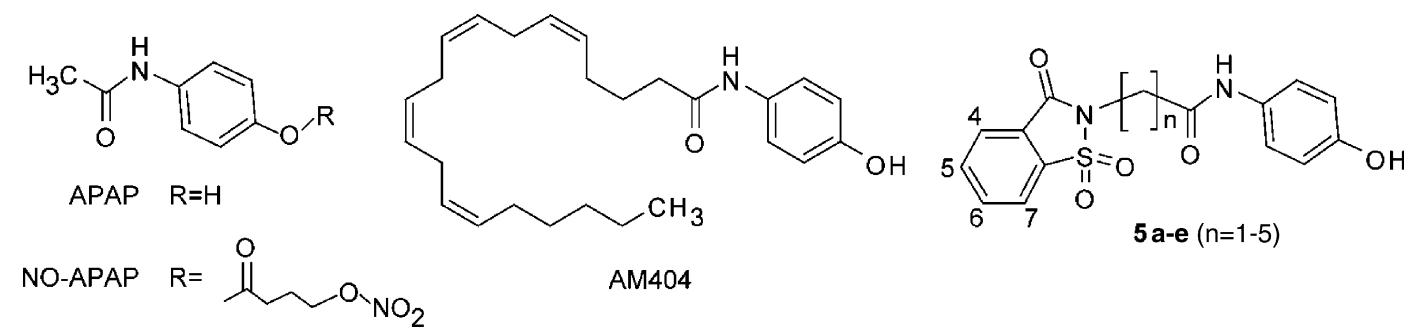

Figure 1. Structures of APAP, NO-APAP, AM 404, and the new acetaminophen analogs 5.

contributing factor. ${ }^{12}$ Also, it has been reported that APAP up-regulates liver Fas and Fas-ligand mRNA expression in vivo, suggesting that APAP liver toxicity is mediated through the Fas pathway. ${ }^{13}$ In addition, the xenobiotic receptor CAR (constitutive androstane receptor) has been identified as a critical regulator of APAP-induced hepatotoxicity, since high doses of APAP induce hepatotoxicity in wild-type mice but not in CAR-null mice; this toxicity is blocked by the CAR antagonist, androstanol. ${ }^{14}$

Upon exploring the idea of modulating the pharmacokinetic profile of the product, a series of compounds bearing the APAP fragment, linked to different lipophilic heterocyclic moieties, was synthesized. ${ }^{15,16}$ Unexpectedly, when the products were tested, some of them were devoid of hepatotoxicity. We describe here the synthesis, in vivo analgesic efficacy, and toxicity of several compounds, 2-(1,1-dioxido-3-oxo-1,2-benzisothiazol-2 $(3 H)$ yl)- $N$-(4-hydroxyphenyl) alkanecarboxamides $\quad 5 \mathbf{a}-\mathbf{e}$ (Fig. 1). The 1,1-dioxo-1,2-dihydrobenzo[d] isothiazol3-one-2-yl moiety is a heterocyclic fragment, which has been extensively used in medicinal chemistry. Such a strategy was expected to lead to the development of compounds with different distribution and in vivo properties. In practice, however, one of them, 5a (SCP-1), has a shorter elimination half-life and clearance than does APAP in isolated rat hepatocytes, ${ }^{17}$ which could yield a more favorable hepatotoxic profile for the product.

\section{Chemistry}

Compound 5a was part of a general project testing libraries of new lipophilic acetaminophen analogs, ${ }^{15,16}$ with heterocyclic fragments linked to the characteristic acylamino(4-hydroxy)phenyl group, essential in APAP. Unexpectedly, a series was identified with reduced hepatotoxicity, in which the heterocycle is the 2-(2,3-dihydro3-oxo-1,2-benzisothiazol-2-yl-1,1-dioxide) linked to the essential fragment by a polymethylene chain, modified by homology, along the set of compounds $\mathbf{5}$ (Fig. 1). The products 5 were prepared according to two alternative methods. Method A (Scheme 1) started by acylation of $p$-aminophenol 2 with the corresponding $\omega$-haloalkanecarbonyl chloride $\mathbf{1}$, to produce the chloroacetamide 3 , which was then reacted with sodium saccharin $\mathbf{4}$, to produce the corresponding compounds $\mathbf{5 a}, \mathbf{b}$, and c. Method B started with the alkylation of the sodium saccharin 4 with the corresponding $\omega$-haloalkanecarboxylic acid $\mathbf{6}$, to produce the acid 7 , which was then used to acylate the aminophenol $\mathbf{2}$, producing $\mathbf{5 d}$ and $\mathbf{e}$ (Scheme 2).

\section{Results and discussion}

An initial comparison of the series 5, based on oral analgesic and hepatotoxic activities, was made to determine which compound would be selected for additional characterization. Table 1 shows the analgesic (acetic

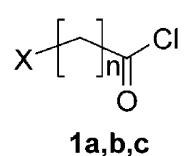

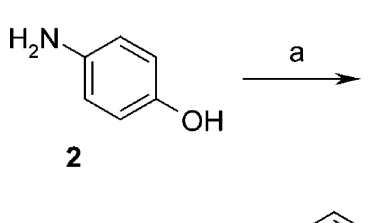<smiles>[X]CC(=O)Nc1ccc(O)cc1</smiles>

$\mathrm{X}=\mathrm{Cl}, \mathrm{Br}$

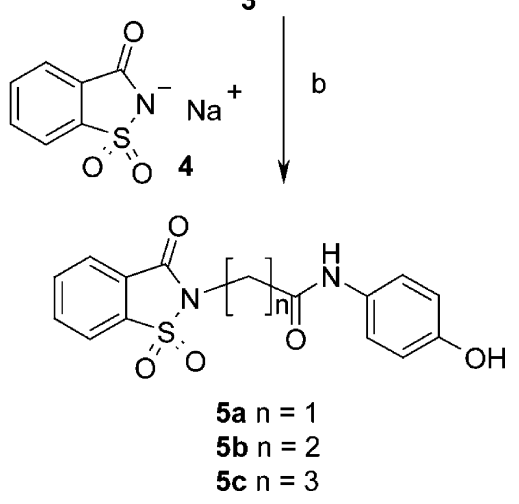

Scheme 1. Synthesis of compounds 5. Method A. Reagents and conditions: (a) AcOH, aq NaAcO, $-5{ }^{\circ} \mathrm{C}$; (b) DMF, 2 h reflux. 


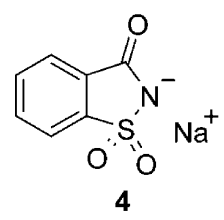<smiles>[X]CCC(=O)O</smiles>

$6 a, b$ $\mathrm{X}=\mathrm{Br} \mathrm{n}=4,5$<smiles>Nc1ccc(O)cc1</smiles>

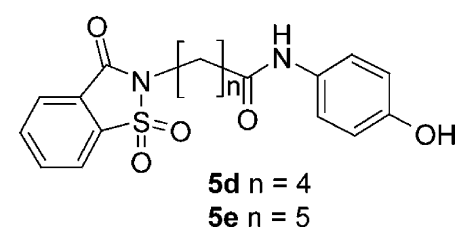

Scheme 2. Synthesis of compounds 5. Method B. Reagents and conditions: (c) DMF, 3 h, reflux; (d) $\mathrm{Cl}_{2} \mathrm{CH}_{2}$, 1-hydroxy-benzotriazole, DCC 2 h, rt.

Table 1. Comparison of analgesic and hepatotoxic effects of compounds 5 and APAP

\begin{tabular}{lllc}
\hline Compound & $n$ & Writhing assay $^{\mathrm{a}}$ & Plasma GPT $^{\mathrm{b}}$ \\
\hline $\mathbf{5 a}$ & 1 & $62.42 \pm 9.45$ & $30.50 \pm 5.05$ \\
$\mathbf{5 b}$ & 2 & $43.80 \pm 12.59$ & $28.85 \pm 4.31$ \\
$\mathbf{5 c}$ & 3 & $28.90 \pm 13.41$ & $82.62 \pm 29.98$ \\
$\mathbf{5 d}$ & 4 & $32.56 \pm 12.79$ & $44.16 \pm 16.32$ \\
$\mathbf{5 e}$ & 5 & $53.72 \pm 11.78$ & $29.52 \pm 5.42$ \\
APAP & & $61.32 \pm 12.45$ & $299.01 \pm 44.30$ \\
\hline
\end{tabular}

${ }^{a}$ Analgesic effects $(\%$ analgesia \pm SEM) were measured $1 \mathrm{~h}$ following a $1 \mathrm{mmol} / \mathrm{kg}$ oral dose of each compound (CD-1 mice, $n=9-16$ per group).

${ }^{\mathrm{b}}$ Plasma GPT (spectrophotometric SF units $/ \mathrm{mL} \pm \mathrm{SD}$ ) was measured $24 \mathrm{~h}$ after a $3.7 \mathrm{mmol} / \mathrm{kg}$ oral dose of each compound (control levels $=24.42 \pm 2.25$ ). In a pilot study, $3.7 \mathrm{mmol} / \mathrm{kg}$ was established as the LD50 for APAP in this strain of mouse (C57BL/6).

acid-induced writhing) ${ }^{18}$ and hepatotoxic (serum glutamic-pyruvic transaminase $(\mathrm{GPT}))^{19}$ properties of compounds 5 and APAP as standard, following oral administration of an equimolar test dose. All compounds $\mathbf{5}$ demonstrated analgesic activity in the writhing assay, with 5a showing activity comparable to APAP. Furthermore, all compounds $\mathbf{5}$ displayed little or no effect on plasma GPT levels, indicating that they are not hepatotoxic. This is in contrast to APAP, which produced a relatively large increase in plasma GPT (9.8-fold increase over 5a). On the basis of its favorable analgesic activity and potential lack of toxicity, $\mathbf{5 a}$ was selected as the prototype of this series for further biological and pharmacological characterization.

A systematic screening to evaluate the in vivo analgesic efficacy of 5a, as compared to that of APAP, was performed. In the chemically induced writhing assay, ${ }^{18}$ both 5a and APAP produced dose-dependent analgesic effects in mice (Fig. 2). On a molar basis, 5a $\left(\mathrm{ED}_{50}=640 \mu \mathrm{mol} / \mathrm{kg}, r^{2}=0.97, p<0.01\right)$ was 2.01 -fold more potent than APAP $\left(\mathrm{ED}_{50}=1290 \mu \mathrm{mol} / \mathrm{kg}\right.$, $\left.r^{2}=0.86, p<0.01\right)$. Dose-response relations in the formalin-induced pain assay ${ }^{20}$ in mice are shown in Figure 3A (5a) and Figure 3B (APAP). Both 5a (SCP-1) and

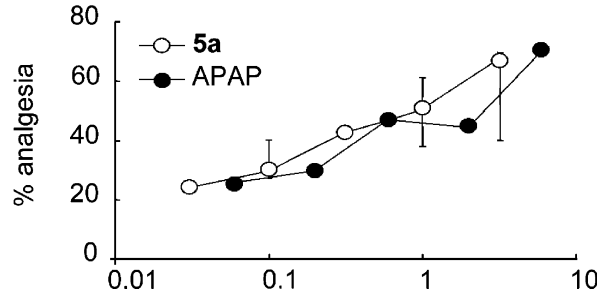

Figure 2. Analgesic effects of SCP-1 and APAP in the writhing assay in mice. Data are expressed as percent analgesia relative to vehicle-treated control ( \pm SEM) 30-40 min after administration of different oral doses of $5 \mathbf{a}$ or APAP.

APAP produced dose-dependent analgesic effects, with 5a $\left(\mathrm{ED}_{50}=260 \mu \mathrm{mol} / \mathrm{kg}, r^{2}=0.29, p<0.01\right)$ being 7.3 fold more potent than APAP $\left(\mathrm{ED}_{50}=1903 \mu \mathrm{mol} / \mathrm{kg}\right.$, $\left.r^{2}=0.35, p<0.01\right)$. In the tail-flick ${ }^{21}$ or hot plate ${ }^{22}$ assays in mice, neither 5a (doses up to $3010 \mu \mathrm{mol} / \mathrm{kg}$ ) nor APAP (doses up to $6620 \mu \mathrm{mol} / \mathrm{kg}$ ) was effective (data not shown), a finding that is consistent with previous studies that have demonstrated no or weak analgesic activity of APAP in these assay. ${ }^{23}$ Moreover, neither $\mathbf{5 a}$ nor APAP was found to possess anti-inflammatory properties in a model of carrageenan-induced paw edema $^{24}$ (Fig. 4).

To evaluate 5a hepatotoxicity and nephrotoxicity, serum GPT levels and glutathione concentrations in liver and kidney homogenates were measured after a high acute dose $(6 \mathrm{mmol} / \mathrm{kg})$ of either 5a or APAP. Glutamic-oxaloacetic transaminase (GOT) activity was also measured as an index of more general toxic effects on such organs as heart, muscle, and spleen. ${ }^{25}$ Compound 5a did not induce signs of liver or kidney damage, as demonstrated by unchanged hepatic and renal glutathione levels (Fig. 5A) and plasma GPT and GOT concentrations (Fig. 5B), as compared with vehicle-treated controls. In contrast, APAP caused significant changes in these markers, reducing hepatic and renal glutathione levels and increasing plasma GPT and GOT. Furthermore, this dose of APAP $(6 \mathrm{mmol} / \mathrm{kg})$ resulted in $40 \%$ (4/10) mortality, whereas none of the mice treated with 


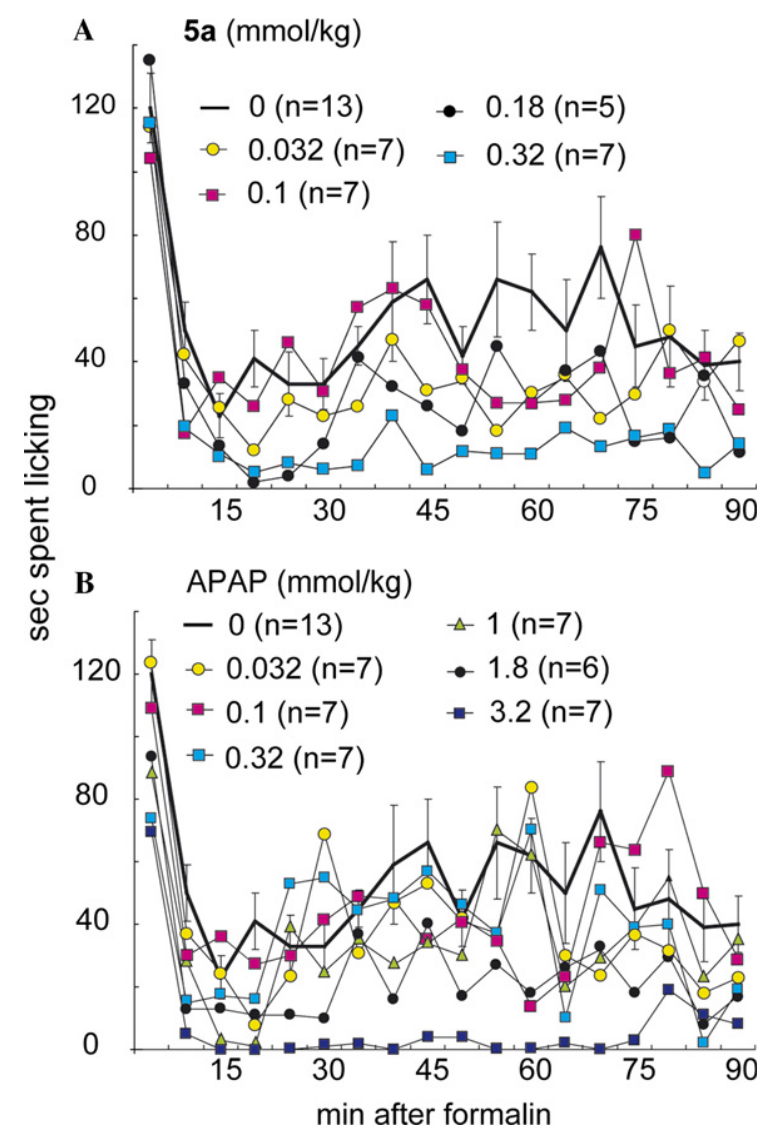

Figure 3. Analgesic effects of SCP-1 (A) and APAP (B) in the formalin assay in mice treated $30 \mathrm{~min}$ before formalin injection. Data are expressed as mean time $( \pm$ SEM) spent licking the injected paw for each 5-min interval during the $90 \mathrm{~min}$ after formalin injection. (See figure for sample sizes.)

$6 \mathrm{mmol} / \mathrm{kg}$ of $5 \mathbf{a}$ died. Because $5 \mathbf{a}$ does not reduce glutathione levels under conditions in which APAP does, it can be concluded that $\mathbf{5 a}$ does not produce NAPQI (or the corresponding NAPQI analog), a profile that would favor decreased hepatotoxicity.

The hepatotoxic effects of 5a were evaluated further in human hepatocytes (HEPG-2) and in primary cultures of normal human liver cells (Fig. 6). In HEPG-2 cells,

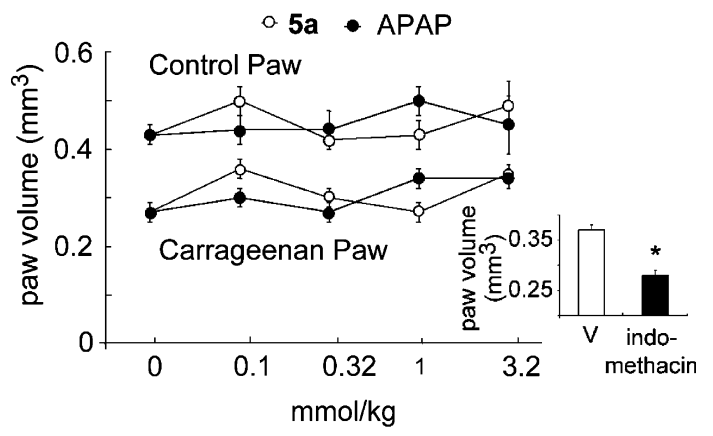

Figure 4. Anti-inflammatory effects of SCP-1, APAP ( $n=4-5$ mice per dose), and indomethacin (inset, $n=8$ per group) on carrageenaninduced paw edema in mice treated 30 min before carrageenan treatment. Data are expressed as percentage of vehicle-treated controls $( \pm$ SEM) $4 \mathrm{~h}$ after injection of carrageenan into one hind paw.
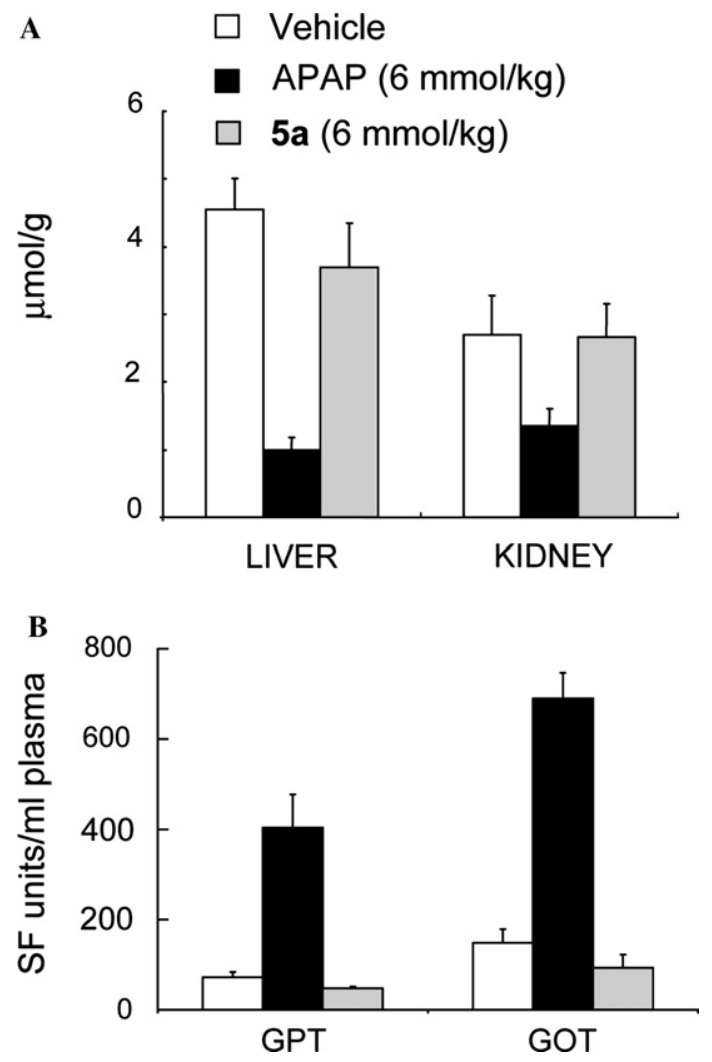

Figure 5. Effects of $6 \mathrm{mmol} / \mathrm{kg} \mathrm{SCP}-1$ and APAP on liver and kidney glutathione (A), and GPT and GOT levels (B) $(n=8-12$ mice in each assay).

5a produced no hepatotoxic effects. In contrast, APAP caused severe hepatocyte damage, and NO-APAP (Fig. 1), a nitrate ester derivative of APAP, ${ }^{26}$ caused an intermediate level of damage in these cells. This liver damage was associated with apoptotic cell death as evidenced by the observation that APAP, unlike 5a, promoted enhanced apoptosis in both HEPG-2 cells (Figs. $6 \mathrm{~A}$ and $\mathrm{B})$ and in primary cultures of human hepatocytes (Figs. 6E and F), while NO-APAP promoted an intermediate level of apoptosis. In this study, we confirmed that APAP up-regulated Fas-ligand in both HEPG-2 cells (Fig. 6C) and primary liver cells (Fig. 6G). In contrast, 5a did not up-regulate the Fas-ligand in these cells (Figs. 6C and G). Tunel and DNA fragmentation as described elsewhere, ${ }^{27}$ as additional apoptosis markers, ${ }^{28}$ followed similar trends of changes (data not shown), as did those of the reported assays. In addition, 5a did not activate CAR in HEPG-2 cells (Fig. 6D) or in normal liver cells (Fig. 6H), as compared with APAP (and NO-APAP), which strongly activated this receptor (Figs. 6D and $\mathrm{H}$ ).

To determine whether the actions of $\mathbf{5 a}$ could be explained by its conversion to APAP, the metabolites generated from 5a were analyzed in samples of mouse urine after a single administration po of $\mathbf{5 a}, 3 \mathbf{m m o l} / \mathrm{kg}$. Urine was collected for $24 \mathrm{~h}$ and analyzed by HPLC-MS, and every peak of the chromatogram was identified. The main metabolites detected in mouse urine are indicated in Scheme 3 and expressed as percentage of total 


\section{HEPG-2 Cells}
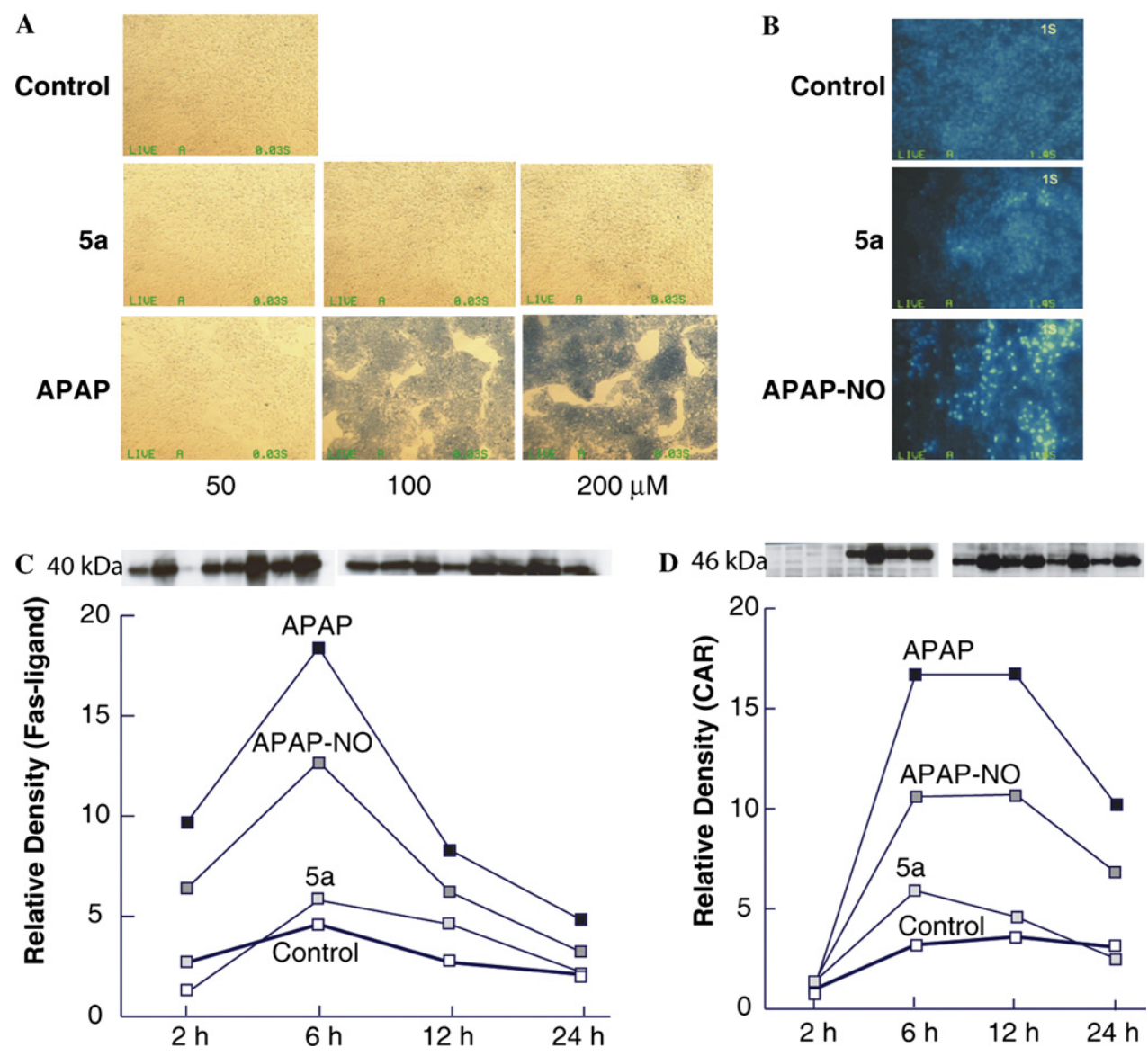

Figure 6. Trypan blue exclusion test indicated that 5a did not induce toxicity in HEPG-2 cells (A). In contrast, APAP induced severe hepatotoxicity at concentrations of 100 and $200 \mu \mathrm{M}$. APAP induced apoptotic cell death as measured by Hoechst staining $(2 \mu \mathrm{M}$ final concentration) in $100 \mu \mathrm{M}$ APAP-treated (6-8 h) HEPG-2 cells. NO-APAP caused an intermediate level of cell death, whereas 5a was ineffective in inducing cell death (B). Time-dependent up-regulation of Fas-ligand showed that APAP caused the highest up-regulation of Fas-ligand in HEPG-2 cells treated with $100 \mu \mathrm{M}$ acetaminophen for the time indicated; NO-APAP caused an intermediate level of up-regulation; and 5a was similar to controls (C). Time-dependent induction of xenobiotic receptor CAR (constitutive androstane receptor), a key regulator of APAP-mediated hepatotoxicity, was measured in HEPG-2 cells treated with $100 \mu \mathrm{M}$ APAP, 5a, and NO-APAP for the times indicated. Quantitation of CAR protein levels by densitometry showed that 5a was unable to activate CAR, which remained at the control level throughout the entire period of the treatment (D). (E) Analysis of the hepatotoxic effects of 5a, APAP, and NO-APAP on primary cultures of human liver cells measured by the Trypan blue exclusion method showed that the hepatotoxic effects exerted by these compounds were comparable to those in HEPG-2 cells, as indicated in A and B. APAP, unlike 5a, caused enhanced apoptosis in primary liver culture as detected by Hoechst staining, while NO-APAP promoted an intermediate level of apoptosis (F). Proapoptotic Fas-ligand up-regulation was significantly enhanced by APAP in human primary liver cultures, whereas 5a had no effect (G). CAR was unaffected by $\mathbf{5 a}$ in human hepatocyte cultures, but was strongly activated by APAP; an intermediate level of activation was produced by NO-APAP $(\mathrm{H})$.

metabolites excreted. Although some untransformed 5a $(0.9 \%)$ is excreted by urine, the major metabolite was the hydrolysis product $\mathbf{8}(38.6 \%)$. Although no reference samples were available, both $\mathbf{5 a}$ and $\mathbf{8}$ apparently formed the corresponding glucuronates $9(32 \%)$ and $\mathbf{1 0}(23.7 \%)$. To be used as a reference product, 8 was prepared by basic hydrolysis of 5a (Scheme 4). Alternatively, 5a resisted one hour reflux in $\mathrm{HCl}$ without decomposition.

Both $5 \mathbf{a}$ and $\mathbf{8}$ were used in HPLC-MS experiments to identify the peaks in the urine samples. As a whole, these results indicate that 5a and APAP are metabolized through different pathways, and that $\mathbf{5 a}$ is not simply a 'pro-drug' of APAP. On the other hand, 5a seems to be easily metabolized in vivo, generating a comparatively hydrosoluble compound $\mathbf{8}$, easily eliminated by urine.
Work is in progress to determine whether this metabolic pathway could be related to the reduced hepatotoxicity of 5 derivatives.

\section{Conclusion}

In summary, our results demonstrate that $\mathbf{5 a}$ has good oral analgesic efficacy, as measured in the formalin and chemically induced writhing assays. When compared with APAP on a molar basis, 5 a was typically a more potent analgesic (2- to 7-fold). Furthermore, the decreased induction of Fas-ligand and CAR by $\mathbf{5 a}$ is consistent with reduced hepatotoxicity, thus contributing to the safety profile of 5a as a potential orally delivered analgesic for the treatment of various pain states in humans. 


\section{Human Hepatocytes in Primary Culture}

E
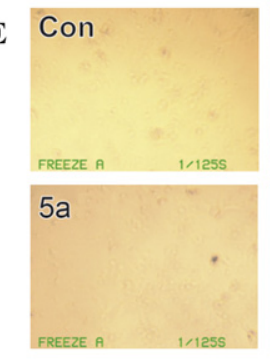

F $\mathrm{CON}$
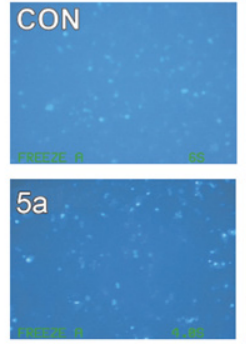

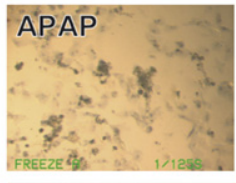

APAP-NO

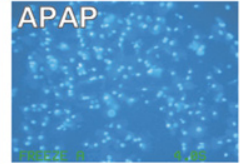

APAPINO

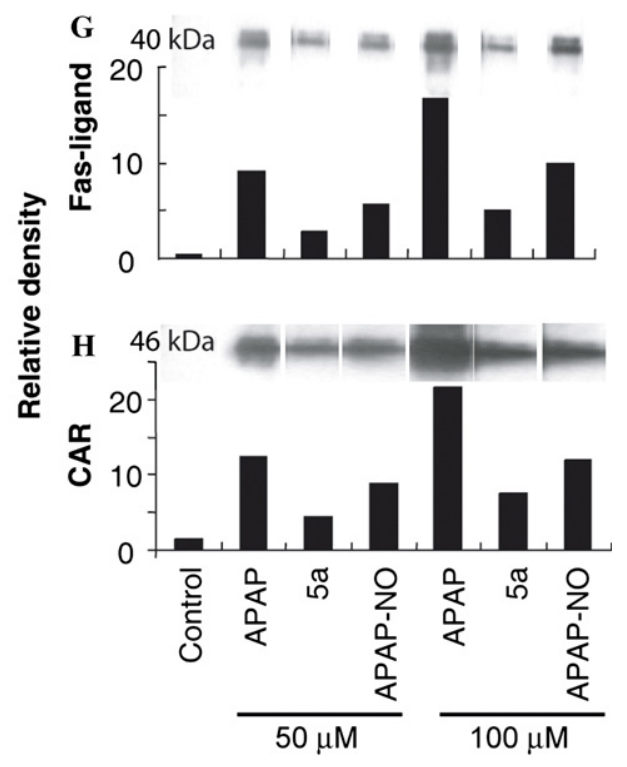

Figure 6. (continued)

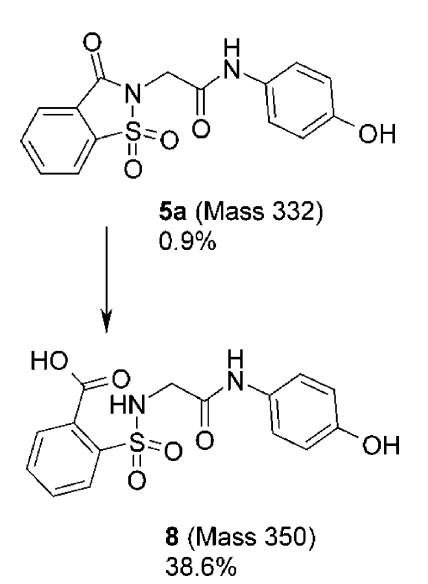

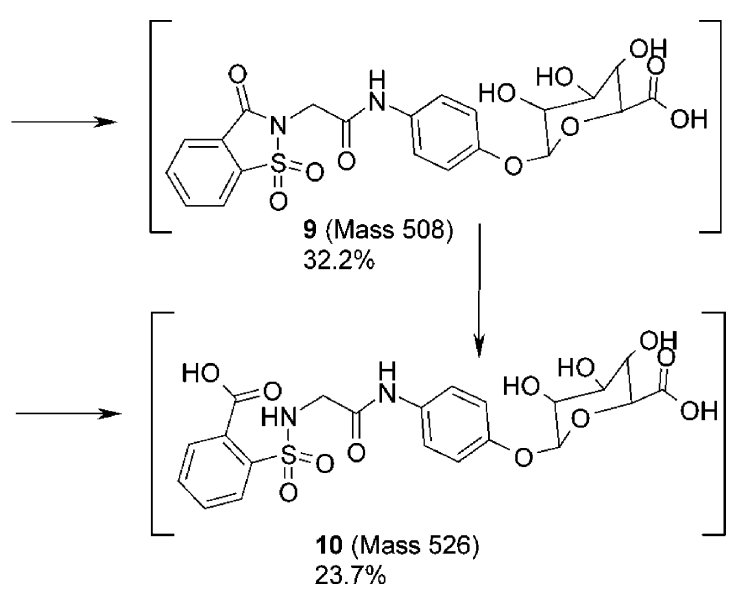

Scheme 3. Metabolites of $\mathbf{5} \mathbf{a}$ detected in mouse urine.<smiles>CC(C)CC(=O)OCC(=O)Nc1ccc(O)cc1</smiles>

Scheme 4. Synthesis of 5a main metabolite. Reagents and conditions: (e) $\mathrm{H}_{2} \mathrm{O}, \mathrm{NaOH}, 20 \mathrm{~min}$, rt.

\section{Experimental}

\subsection{Materials}

Melting points were recorded on an Electrothermal IA6304 instrument and are uncorrected. IR spectra were obtained on a Perkin-Elmer FTIR 1725X spectrometer. ${ }^{1} \mathrm{H}$ NMR spectra were obtained on a Varian Unity 300 spectrometer at $300 \mathrm{MHz}$. HPLC-MS analyses were performed on an Agilent 1100 apparatus. Flash chromatography was conducted using Merck Kieselgel 60 (230-400 mesh). Solvents and reagents were of commercial origin, and were purified by standard procedures.

\subsection{Chemistry}

\subsubsection{Method A}

5.2.1.1. General procedure for the synthesis of $\mathrm{N}-(4-$ hydroxyphenyl)- $\omega$-haloalkane-carboxamides (3). The corresponding $\omega$-haloalkaneacylchloride $(1,65 \mathrm{mmol})$ was added dropwise to a solution of 4-aminophenol (2, $6.5 \mathrm{~g}, 54 \mathrm{mmol})$, acetic acid $(45 \mathrm{~mL})$, and a saturated solution of sodium acetate $(45 \mathrm{~mL})$ at $-5^{\circ} \mathrm{C}$. After the 
addition was completed, the mixture was stirred at $0{ }^{\circ} \mathrm{C}$ for $2 \mathrm{~h}$ and then filtered to give a white solid. The solid was recrystallized from water to yield $\mathbf{3}$ as a colorless crystalline solid.

5.2.1.2. $\mathrm{N}$-(4-Hydroxyphenyl)-2-chloroacetamide (3a). The general method was applied to chloroacetylchloride (1a, $6.7 \mathrm{~g}, 65 \mathrm{mmol})$. The product 3a was obtained as a colorless crystalline solid (7.6 g, 69\% yield). Mp 144 $146{ }^{\circ} \mathrm{C} .{ }^{1} \mathrm{H}$ NMR (DMSO- $\left.d_{6}, 300 \mathrm{MHz}\right) \delta: 10.04(\mathrm{~s}$, $1 \mathrm{H}, \mathrm{NH}), 9.27(\mathrm{~s}, 1 \mathrm{H}, \mathrm{OH}), 7.36(\mathrm{~d}, 2 \mathrm{H}, J=8.6 \mathrm{~Hz}$, $\mathrm{H}-2,6 p$-aminophenol), $6.71(\mathrm{~d}, 2 \mathrm{H}, J=8.6 \mathrm{~Hz}, \mathrm{H}-3,5$ p-aminophenol), $4.19\left(\mathrm{~s}, 2 \mathrm{H}, \mathrm{CH}_{2}\right)$. Anal. Calcd for $\mathrm{C}_{8} \mathrm{H}_{8} \mathrm{ClNO}_{2}$ : C, 51.77; $\mathrm{H}, 4.34 ; \mathrm{N}, 7.55 ; \mathrm{Cl}, 19,10$. Found, C, 51.56; H, 4.57; N, 7.36; Cl, 19.33.

5.2.1.3. $\quad N$-(4-Hydroxyphenyl)-3-bromopropionamide (3b). The general method was applied to 3-bromopropionyl chloride (1b, $11 \mathrm{~g}, 65 \mathrm{mmol})$, yielding $\mathbf{3 b}$ as a colorless crystalline solid $\left(8.2 \mathrm{~g}, 63 \%\right.$ yield). Mp $130-132{ }^{\circ} \mathrm{C}$. ${ }^{1} \mathrm{H}$ NMR (DMSO- $\left.d_{6}, 300 \mathrm{MHz}\right) \delta: 9.79(\mathrm{~s}, 1 \mathrm{H}, \mathrm{NH})$, $9.18(\mathrm{~s}, 1 \mathrm{H}, \mathrm{OH}), 7.37(\mathrm{~d}, 2 \mathrm{H}, J=8.7 \mathrm{~Hz}, \mathrm{H}-2,6 p$-aminophenol), $6.79(\mathrm{~d}, 2 \mathrm{H}, J=8.7 \mathrm{~Hz}, \mathrm{H}-3,5$-aminophenol), $3.71\left(\mathrm{t}, 2 \mathrm{H}, \mathrm{C}(\alpha) \mathrm{H}_{2}\right), 2.89\left(\mathrm{t}, 2 \mathrm{H}, \mathrm{C}(\beta) \mathrm{H}_{2}\right)$. Anal. Calcd for $\mathrm{C}_{9} \mathrm{H}_{10} \mathrm{BrNO}_{2}$ : C, 44.29; H, 4.13; N, 5.74; $\mathrm{Br}$, 32,74 . Found, C, 44.46; H, 4.17; N, 5.56; Br, 32.53 .

5.2.1.4. $\quad N$-(4-Hydroxyphenyl)-4-chlorobutyrylamide (3c). The general method was applied to 4-chlorobutyrylchloride (1c, $9.2 \mathrm{~g}, 65 \mathrm{mmol}$ ), to yield $3 \mathrm{c}$ as colorless crystalline solid $\left(6.5 \mathrm{~g}, 56 \%\right.$ yield). Mp $112-114{ }^{\circ} \mathrm{C} .{ }^{1} \mathrm{H}$ NMR (DMSO- $\left.d_{6}, 300 \mathrm{MHz}\right) \delta: 9.69(\mathrm{~s}, 1 \mathrm{H}, \mathrm{NH}), 9.17$ $(\mathrm{s}, 1 \mathrm{H}, \mathrm{OH}), 7.35(\mathrm{~d}, 2 \mathrm{H}, J=8.8 \mathrm{~Hz}, \mathrm{H}-2,6$-aminophenol), $6.68(\mathrm{~d}, 2 \mathrm{H}, J=8.8 \mathrm{~Hz}, \mathrm{H}-3,5 p$-aminophenol), $3.68\left(\mathrm{t}, 2 \mathrm{H}, \mathrm{C}(\alpha) \mathrm{H}_{2}\right), 2.41\left(\mathrm{t}, 2 \mathrm{H}, \mathrm{C}(\chi) \mathrm{H}_{2}\right), 2.25(\mathrm{~m}$, $\left.2 \mathrm{H}, \mathrm{C}(\beta) \mathrm{H}_{2}\right)$. Anal. Calcd for $\mathrm{C}_{10} \mathrm{H}_{12} \mathrm{ClNO}_{2}$ : C, 56.21; $\mathrm{H}, 5.66 ; \mathrm{N}, 6.56 ; \mathrm{Cl}, 16,59$. Found, $\mathrm{C}, 56.40 ; \mathrm{H}, 5.57$; $\mathrm{N}, 6.66 ; \mathrm{Cl}, 16.53$.

5.2.1.5. General procedure for the synthesis of $\mathrm{N}-(4-$ hydroxyphenyl)-2-[2,3-dihydro-3-oxo-1,2-benzisothiazol2-yl-1,1-dioxide)-alkanecarboxamides (5). A solution of $N$-(4-hydroxyphenyl)- $\omega$-haloalkanecarboxamide (3, $20 \mathrm{mmol})$ and sodium saccharin $(4,6.2 \mathrm{~g}, 30 \mathrm{mmol})$ in DMF $(16 \mathrm{~mL})$ was heated to reflux with stirring for $2 \mathrm{~h}$. At the end of this time, the $\mathrm{NaCl}$ that precipitated was removed by filtration and the filtrate was evaporated under reduced pressure. The residue was partitioned between EtOAc $(180 \mathrm{~mL})$ and water $(100 \mathrm{~mL})$. The organic layer was washed with brine $(100 \mathrm{~mL})$ and dried $\left(\mathrm{Na}_{2} \mathrm{SO}_{4}\right)$, and the solvent was removed under reduced pressure to afford a white solid. The crude solid was recrystallized from ethanol/ $\mathrm{H}_{2} \mathrm{O}(8: 1)$ to furnish 5 as a colorless crystalline solid.

5.2.1.6. $\quad N$-(4-Hydroxyphenyl)-2-[2,3-dihydro-3-oxo1,2-benzisothiazol-2-yl-1,1-dioxidel-acetamide (5a). The general method was applied to $\mathrm{N}$-(4-hydroxyphenyl)-2chloroacetamide (3a, $3.7 \mathrm{~g}, 20 \mathrm{mmol}$ ) to yield $\mathbf{5 a}$ as a colorless crystalline solid $(5.7 \mathrm{~g}, 86 \%)$. Mp $204-206^{\circ} \mathrm{C}$. IR $\left(\mathrm{KBr}, \mathrm{cm}^{-1}\right)$; 3339, 3100, 1742, 1676, 1509, 1449, 1332, $1185,1063 .{ }^{1} \mathrm{H}$ NMR (DMSO- $\left.d_{6}, 300 \mathrm{MHz}\right) \delta: 10.06(\mathrm{~s}$, $1 \mathrm{H}, \mathrm{NH}), 9.27(\mathrm{~s}, 1 \mathrm{H}, \mathrm{OH}), 8.33(\mathrm{~d}, 1 \mathrm{H}, J=7.4 \mathrm{~Hz}, \mathrm{H}-4$ of 2-[2,3-dihydro-3-oxo-1,2-benzisothiazol-2-yl-1,1-dioxide]), 8.16-7.95 (m, 3H, H-5,6,7 of 2-[2,3-dihydro-3oxo-1,2-benzisothiazol-2-yl-1,1-dioxide]), 7.31 (d, 2H, $J=8.7 \mathrm{~Hz}, \quad \mathrm{H}-2,6 \quad p$-aminophenol), $6.68 \quad(\mathrm{~d}, \quad 2 \mathrm{H}$, $J=8.7 \mathrm{~Hz}, \mathrm{H}-3,5$ p-aminophenol), $4.49\left(\mathrm{~s}, 2 \mathrm{H}, \mathrm{CH}_{2}\right)$. Anal. Calcd for $\mathrm{C}_{15} \mathrm{H}_{12} \mathrm{~N}_{2} \mathrm{O}_{5} \mathrm{~S}$ : C, 54.21; H, 3.64; N, 8.43; S, 9.65. Found, C, 54.16; H, 3.77; N, 8.36; S, 9.48.

5.2.1.7. $\quad N$-(4-Hydroxyphenyl)-3-[2,3-dihydro-3-oxo1,2-benzisothiazol-2-yl-1,1-dioxidel-propionamide (5b). The general method was applied to $N$-(4-hydroxyphenyl)-3-bromopropionamide (3b) $(4.9 \mathrm{~g}, 20 \mathrm{mmol})$ to yield $\mathbf{5 b}$ as a colorless crystalline solid $(5.9 \mathrm{~g}, 85 \%)$. $\mathrm{Mp} 237-239^{\circ} \mathrm{C}$, IR $\left(\mathrm{KBr}, \mathrm{cm}^{-1}\right) ; 3382,1746,1648$, $1551,1438,1312,1174,1157 .{ }^{1} \mathrm{H}$ NMR (DMSO- $d_{6}$, $300 \mathrm{MHz}) \delta: 9.78(\mathrm{~s}, 1 \mathrm{H}, \mathrm{NH}), 9.16(\mathrm{~s}, 1 \mathrm{H}, \mathrm{OH}), 8.28$ (d, $1 \mathrm{H}, J=6.9 \mathrm{~Hz}, 4-\mathrm{H}$ of 2-[2,3-dihydro-3-oxo-1,2benzisothiazol-2-yl-1,1-dioxide]), 8.11-7.95 (m, 3H, $\mathrm{H}-5,6,7$ of 2-[2,3-dihydro-3-oxo-1,2-benzisothiazol-2-yl1,1-dioxide]), 7.29 (d, 2H, $J=8.7 \mathrm{~Hz}, \mathrm{H}-2,6 p$-aminophenol), 6.67 (d, $2 \mathrm{H}, J=8.7 \mathrm{~Hz}, \mathrm{H}-3,5 p$-aminophenol), 4.03 $\left(\mathrm{t}, 2 \mathrm{H}, J=7.3 \mathrm{~Hz}, \mathrm{C}(\alpha) \mathrm{H}_{2}\right), 2.77(\mathrm{t}, 2 \mathrm{H}, J=7.6 \mathrm{~Hz}$, $\left.\mathrm{C}(\beta) \mathrm{H}_{2}\right)$. Anal. Calcd for $\mathrm{C}_{16} \mathrm{H}_{14} \mathrm{~N}_{2} \mathrm{O}_{5} \mathrm{~S}$ : C, 55.48; $\mathrm{H}$, 4.07; N, 8.08; S, 9.26. Found: C, 55.22; H, 4.22; N, 8.04; S, 9.19 .

5.2.1.8. $\mathrm{N}$-(4-Hydroxyphenyl)-4-[2,3-dihydro-3-oxo-1,2benzisothiazol-2-yl-1,1-dioxidel-butyrylamide (5c). A solution of 4-chloro- $N$-(4-hydroxyphenyl)-butyrylamide (3c, $5.8 \mathrm{~g}, 27 \mathrm{mmol})$, anhydrous sodium saccharin $(4,8.4 \mathrm{~g}$, $41 \mathrm{mmol})$ and $\mathrm{NaI}(0.85 \mathrm{~g}, 5.6 \mathrm{mmol})$ in dry DMF $(20 \mathrm{~mL})$ was heated to $90^{\circ} \mathrm{C}$ for $1.5 \mathrm{~h}$. The reaction was allowed to cool to room temperature, the precipitate was filtered, and the filtrate was evaporated under reduced pressure. The residue was dissolved in EtOAc $(280 \mathrm{~mL})$, washed, respectively, with water $(100 \mathrm{~mL})$ and brine solution $(100 \mathrm{~mL})$, and dried $\left(\mathrm{Na}_{2} \mathrm{SO}_{4}\right)$. The solvent was removed under reduced pressure and the white solid residue was recrystallized in ethanol/ $\mathrm{H}_{2} \mathrm{O}(10: 1)$ to furnish $\mathbf{5 c}$ as a white crystalline solid $(7.9 \mathrm{~g}, 82 \%)$. Mp $190-192{ }^{\circ} \mathrm{C}$. ${ }^{1} \mathrm{H}$ NMR (DMSO- $\left.d_{6}, 400 \mathrm{MHz}\right) \delta: 9.57(\mathrm{~s}, 1 \mathrm{H}, \mathrm{NH}), 9.06$ (s, 1H, OH), 8.25-7.95 (m, 4H, H-4,5,6,7 of 2-[2,3-dihydro3-oxo-1,2-benzisothiazol-2-yl-1,1-dioxide]), 7.33 (d, $2 \mathrm{H}$, 8.8. Hz, H-2,6 p-aminophenol), $6.70(\mathrm{~d}, 2 \mathrm{H}, 8.8 \mathrm{~Hz}, \mathrm{H}-$ 3,5 p-aminophenol), $3.78\left(\mathrm{t}, 2 \mathrm{H}, 7.4 \mathrm{~Hz}, \mathrm{C}(\alpha) \mathrm{H}_{2}\right), 2.37$ (t, $\left.2 \mathrm{H}, 7.4 \mathrm{~Hz}, \mathrm{C}(\chi) \mathrm{H}_{2}\right), 2.02\left(\mathrm{~m}, 2 \mathrm{H}, \mathrm{C}(\beta) \mathrm{H}_{2}\right)$. Anal. Calcd for $\mathrm{C}_{17} \mathrm{H}_{16} \mathrm{~N}_{2} \mathrm{O}_{5} \mathrm{~S}$ : C, 56.66; H, 4.44; N, 7.77; S, 8.90. Found: C, 56.72; H, 4.47; N, 7.75; S, 8.81.

\subsubsection{Method B}

5.2.2.1. General procedure for the synthesis of $2-(2,3-$ dihydro-3-oxo-1,2-benzisothiazol-2-yl-1,1-dioxide)alkanecarboxylic acids (7). A solution of anhydrous sodium saccharin $(4,8.6 \mathrm{~g}, 42 \mathrm{mmol})$ and the corresponding $\omega$-haloalkanecarboxylic acid $(6,4.5 \mathrm{~g}, 25 \mathrm{mmol})$ in DMF $(20 \mathrm{~mL})$ was heated to reflux for $3 \mathrm{~h}$. The reaction mixture was allowed to cool to room temperature, the precipitate was filtered, and the filtrate was evaporated under reduced pressure. The residue was dissolved in EtOAc $(200 \mathrm{~mL})$, washed with brine $(2 \times 130 \mathrm{~mL})$, and dried $\left(\mathrm{Na}_{2} \mathrm{SO}_{4}\right)$. The solvent was removed under reduced pressure and the white solid residue was recrystal- 
lized from EtOAc/hexane to furnish 7 as a crystalline solid.

5.2.2.2. 5-(2,3-Dihydro-3-oxo-1,2-benzisothiazol-2-yl1,1-dioxide)pentanoic acid (7a). The general method was applied to 5-bromopentanoic acid (6a, $4.5 \mathrm{~g}, 25 \mathrm{mmol})$ to furnish $7 \mathbf{a}$ as a crystalline solid $(5.0 \mathrm{~g}, 71 \%)$. Mp $82^{\circ} \mathrm{C}$. IR $\left(\mathrm{KBr}, \mathrm{cm}^{-1}\right) ; 2955,2866,1701,1459,1411,1333$, 1290, 1258, 1182, 1059, 923, 749. ${ }^{1} \mathrm{H}$ NMR $\left(\mathrm{CD}_{3} \mathrm{OD}\right.$, $300 \mathrm{MHz}) \delta:$ 7.93-7.72 (m, 4H, H-4,5,6,7 of 2-[2,3-dihydro-3-oxo-1,2-benzisothiazol-2-yl-1,1-dioxide]), 3.63 (t, $\left.2 \mathrm{H}, \quad J=6.6 \mathrm{~Hz}, \quad \mathrm{C}(\alpha) \mathrm{H}_{2}\right), 2.22(\mathrm{t}, \quad 2 \mathrm{H}, \quad J=7.3 \mathrm{~Hz}$, $\left.\mathrm{C}(\delta) \mathrm{H}_{2}\right), 1.78-1.48\left(\mathrm{~m}, 4 \mathrm{H}, \mathrm{C}(\beta) \mathrm{H}_{2}, \mathrm{C}(\chi) \mathrm{H}_{2}\right)$. Anal. Calcd for $\mathrm{C}_{12} \mathrm{H}_{13} \mathrm{NO}_{5} \mathrm{~S}$. $\mathrm{H}_{2} \mathrm{O}$ : C, 47.83; H, 5.02; N, 4.65; S, 10.62 . Found: C, 47.55; H, 4.92; N, 5.54; S, 10.50 .

5.2.2.3. 6-(2,3-Dihydro-3-oxo-1,2-benzisothiazol-2-yl1,1-dioxide)hexanoic acid (7b). The general method was applied to 6-bromohexanoic acid $(6 \mathbf{b}, 4.9 \mathrm{~g}, 25 \mathrm{mmol})$ to yield 7b as a crystalline solid. $\mathrm{Mp} 93^{\circ} \mathrm{C}$. IR (KBr, cm $\left.{ }^{-1}\right): 2955$, 2866, 1701, 1459, 1411, 1333, 1290, 1258, 1182, 1059, 923, 749. ${ }^{1} \mathrm{H}$ NMR $\left(\mathrm{CD}_{3} \mathrm{OD}, 300 \mathrm{MHz}\right) \delta: 8.08-7.93$ (m, 4H, H4,6,7 of 2-[2,3-dihydro-3-oxo-1,2-benzisothiazol-2-yl-1,1dioxide]), $3.76\left(\mathrm{t}, 2 \mathrm{H}, J=7.3 \mathrm{~Hz}, \mathrm{C}(\alpha) \mathrm{H}_{2}\right), 2.31(\mathrm{t}, 2 \mathrm{H}$, $\left.J=6.9 \mathrm{~Hz}, \mathrm{C}(\varepsilon) \mathrm{H}_{2}\right), 1.84\left(\mathrm{~m}, 2 \mathrm{H}, \mathrm{CH}_{2}\right), 1.67(\mathrm{~m}, 2 \mathrm{H}$, $\left.\mathrm{CH}_{2}\right), 1.45\left(\mathrm{~m}, 2 \mathrm{H}, \mathrm{CH}_{2}\right)$. Anal. Calcd for $\mathrm{C}_{13} \mathrm{H}_{15} \mathrm{NO}_{5} \mathrm{~S} \cdot-$ $\mathrm{H}_{2} \mathrm{O}$ : C, 49.52; H, 5.43; N, 4.44; S, 10.15. Found: C, 49.20, H, 4.99; N, 4.48; S, 10.02 .

5.2.2.4. General procedure for the synthesis of $N-(4-$ hydroxyphenyl)-2-[2,3-dihydro-3-oxo-1,2-benzisothiazol2-yl-1,1-dioxidel-alkanecarboxamides (5). To a solution containing the corresponding acid 7 (20 mmol), 4-aminophenol (2, $2.2 \mathrm{~g}, 20 \mathrm{mmol})$, and 1-hydroxy-1 $H$-benzotriazole $(2.7 \mathrm{~g})$ in $\mathrm{CH}_{2} \mathrm{Cl}_{2},(80 \mathrm{~mL})$ previously cooled to $0{ }^{\circ} \mathrm{C}$, a solution of 1,3 -dicyclohexylcarbodiimide $(4.1 \mathrm{~g}$, $20 \mathrm{mmol})$ in $\mathrm{CH}_{2} \mathrm{Cl}_{2}(30 \mathrm{~mL})$ was added. After the addition was completed, the reaction mixture was stirred at room temperature for $2 \mathrm{~h}$. The resulting solid was filtered and recrystallized from ethanol/water (10:1) to furnish the corresponding $\mathbf{5}$ as a white crystalline solid.

5.2.2.5. $N$-(4-Hydroxyphenyl)-5-[2,3-dihydro-3-oxo-1,2benzisothiazol-2-yl-1,1-dioxidel-pentamide (5d). The general method was applied to the acid $7 \mathbf{a}(5.6 \mathrm{~g}, 20 \mathrm{mmol})$, to obtain $5 \mathbf{d}$ as a white crystalline solid (4.1 g, 54\%). Mp 162-164 ${ }^{\circ} \mathrm{C}$. IR $\left(\mathrm{KBr}, \mathrm{cm}^{-1}\right)$; 3324, 1722, 1661, 1547, $1521,1323,1312,1184 .{ }^{1} \mathrm{H}$ NMR (DMSO- $\left.d_{6}, 300 \mathrm{MHz}\right)$ $\delta: 9.63(\mathrm{~s}, 1 \mathrm{H}, \mathrm{NH}), 9.06(\mathrm{~s}, 1 \mathrm{H}, \mathrm{OH}), 8.32(\mathrm{~d}, 1 \mathrm{H}$, $J=7.2 \mathrm{~Hz}, \quad \mathrm{H}-4$ of 2-[2,3-dihydro-3-oxo-1,2-benzisothiazol-2-yl-1,1-dioxide]), 8.12-7.95 (m, 3H, H-5,6,7 of 2-[2,3-dihydro-3-oxo-1,2-benzisothiazol-2-yl-1,1-dioxide]), 7.25 (d, 2H, $J=8.8 \mathrm{~Hz}, \mathrm{H}-2,6$-aminophenol), 6.67 (d, 2H, $J=8.8 \mathrm{~Hz}, \mathrm{H}-3,5$-aminophenol), $3.71(\mathrm{t}, 2 \mathrm{H}$, $\left.J=6.8 \mathrm{~Hz}, \mathrm{C}(\alpha) \mathrm{H}_{2}\right), 2.33\left(\mathrm{t}, 2 \mathrm{H}, J=6.2 \mathrm{~Hz}, \mathrm{C}(\delta) \mathrm{H}_{2}\right)$, 1.71-1.64 (m, 4H, $\left.\mathrm{C}(\beta) \mathrm{H}_{2}, \mathrm{C}(\chi) \mathrm{H}_{2}\right)$. Anal. Calcd for $\mathrm{C}_{18} \mathrm{H}_{18} \mathrm{~N}_{2} \mathrm{O}_{5} \mathrm{~S}$ : C, 57.74; H, 4.85; N, 7.48; S 8.56. Found: C, 57.99; H, 4.88; N, 7.42; S, 8.44.

5.2.2.6. $\quad \mathrm{N}$-(4-Hydroxyphenyl)-6-[2,3-dihydro-3-oxo1,2-benzisothiazol-2-yl-1,1-dioxide]-hexamide (5e). The general method was applied to the acid $7 \mathbf{b}(5.9 \mathrm{~g}$,
$20 \mathrm{mmol}$ ), to obtain $\mathbf{5 e}$ as a white crystalline solid (4.6 g, 59\%). Mp 131-133 ${ }^{\circ} \mathrm{C}$. IR $\left(\mathrm{KBr}, \mathrm{cm}^{-1}\right)$; 3319, $1721,1661,1552,1335,1322,1181 .{ }^{1} \mathrm{H}$ NMR (DMSO$\left.d_{6}, 300 \mathrm{MHz}\right) \delta: 9.58(\mathrm{~s}, 1 \mathrm{H}, \mathrm{NH}), 9.09(\mathrm{~s}, 1 \mathrm{H}, \mathrm{OH})$, $8.29(\mathrm{~d}, 1 \mathrm{H}, J=7.7 \mathrm{~Hz}, \mathrm{H}-4$ of 2-[2,3-dihydro-3-oxo1,2-benzisothiazol-2-yl-1,1-dioxide]), 8.12-7.95 (m, 3H, H-5,6,7 of 2-[2,3-dihydro-3-oxo-1,2-benzisothiazol-2-yl1,1-dioxide]), 7.27 (d, 2H, $J=8.4 \mathrm{~Hz}, \mathrm{H}-2,6$-aminophenol), 6.71 (d, $2 \mathrm{H}, J=8.6 \mathrm{~Hz}, \mathrm{H}-3,5$-aminophenol), $3.73\left(\mathrm{t}, 2 \mathrm{H}, J=7.0 \mathrm{~Hz}, \mathrm{C}(\alpha) \mathrm{H}_{2}\right), 2.27(\mathrm{t}, 2 \mathrm{H}, J=7.0 \mathrm{~Hz}$, $\left.\mathrm{C}(\varepsilon) \mathrm{H}_{2}\right), 1.77-1.72\left(\mathrm{~m}, 2 \mathrm{H}, \mathrm{C}(\beta) \mathrm{H}_{2}\right), 1.63-1.57(\mathrm{~m}, 2 \mathrm{H}$, $\left.\mathrm{C}(\chi) \mathrm{H}_{2}\right), 1.39-1.34\left(\mathrm{~m}, 2 \mathrm{H}, \mathrm{C}(\delta) \mathrm{H}_{2}\right)$. Anal. Calcd for $\mathrm{C}_{19} \mathrm{H}_{20} \mathrm{~N}_{2} \mathrm{O}_{5} \mathrm{~S}: \mathrm{C}, 58.75 ; \mathrm{H}, 5.11 ; \mathrm{N}, 7.01 ; \mathrm{S}, 8.25$. Found: C, 58.57; H, 5.24; N, 7.28; S, 8.13.

\subsubsection{Hydrolysis of $5 b$}

5.2.3.1. 2 -\{[(4-Hydroxyphenylcarbamoyl)methyl]sulfamoyl\}benzoic acid (8). Two grams of 5a $(6 \mathrm{mmol})$ was suspended in $10 \mathrm{~mL}$ of $10 \%$ aqueous $\mathrm{NaOH}$, and after $30 \mathrm{~min}$, suspension turned into a solution. Then 8 was isolated by neutralization of the reaction mixture with $1 \mathrm{~N} \mathrm{HCl}$ and extraction with ethyl acetate. $2 \mathrm{~g}$ of 6 was obtained $(98 \%)$. Mp $193-195^{\circ} \mathrm{C}$. IR $\left(\mathrm{KBr}, \mathrm{cm}^{-1}\right)$; 3364, 3320, 2969, 1701, 1642, 1610, 1537, 1400, 1331, 1271, 1157, 1108. ${ }^{1} \mathrm{H}$ NMR (DMSO- $\left.d_{6}, 300 \mathrm{MHz}\right) \delta$ : 13.50 (br s, $1 \mathrm{H}, \mathrm{COOH}) ; 9.70$ (s, 1H, CONH); 9.18 (br s, $1 \mathrm{H}, \mathrm{OH}) ; 7.94(\mathrm{~d}, 1 \mathrm{H}, J=7.8 \mathrm{~Hz}, \mathrm{H}-6$ benzoic acid); 7.74-7.67 (m, 3H, H-4,5 benzoic acid $\left.+\mathrm{SO}_{2} \mathrm{NH}\right) ; 7.39$ (br s, 1H, H-3 benzoic acid); $7.20(\mathrm{~d}, 2 \mathrm{H}, J=8.4 \mathrm{~Hz}$, $\mathrm{H}-2,6$-aminophenol); $6.65(\mathrm{~d}, 2 \mathrm{H}, J=8.4 \mathrm{~Hz}, \mathrm{H}-3,5$ p-aminophenol); $3.73\left(\mathrm{~s}, 2 \mathrm{H}, \mathrm{CH}_{2}\right)$. Anal. Calcd for $\mathrm{C}_{15} \mathrm{H}_{14} \mathrm{~N}_{2} \mathrm{O}_{6} \mathrm{~S}: \mathrm{C}, 51.42 ; \mathrm{H}, 4.03 ; \mathrm{N}, 8.00 ; \mathrm{S} 9.15$. Found: C, 51.30; H, 4.14; N, 8.11; S, 9.03.

\subsection{Biology}

5.3.1. Analgesic assays. All tests were performed on male CD-1 mice (25-35 g; Charles River Breeding Laboratories, Wilmington, MA). Compounds 5 (St. Charles Pharmaceuticals, New Orleans, LA), or APAP (Sigma, St. Louis, MO) in amounts as established in specific protocols was suspended in the vehicle (Agent K, 0.2\%, Bioserve, or Labrafil 1944, Gottefosee, France). Drugs or vehicle was administered per os (po) by esophageal cannulation under brief halothane anesthesia to animals fasted overnight.

5.3.2. Chemically induced writhing. ${ }^{18}$ In this model of visceral pain, abdominal contractions (writhing) were induced in mice by an intraperitoneal (ip) injection of $0.4 \%$ acetic acid at a dose of $10 \mathrm{~mL} / \mathrm{kg} 25 \mathrm{~min}$ after drug administration. The numbers of writhes, characterized by a wave of contraction of the abdominal muscles followed by extension of the hind limbs, were counted for $10 \mathrm{~min}$ beginning $5 \mathrm{~min}$ after the acetic acid injection. Data were analyzed using a two-way ANOVA (drug $\times$ dose), followed by Tukey's post hoc comparisons.

5.3.3. Formalin-induced pain. ${ }^{20}$ Mice were injected subcutaneously (sc) into the plantar surface of one hind paw with $30 \mu \mathrm{L}$ of $5 \%$ buffered formalin acetate $30 \mathrm{~min}$ after drug administration. The amount of time the animal spent licking the injected paw was recorded for blocks 
of 5 min during the 90 min following formalin injection. Animal behavior was observed with the help of a mirror positioned at a $45^{\circ}$ angle under a specially designed clear Plexiglas cage $(16 \times 32 \times 32 \mathrm{~cm})$, which allowed an unobstructed view of the animal's paw. To minimize stress, mice were habituated to the test box for $90 \mathrm{~min}$ on the day before testing. Data in the formalin assay were analyzed using a three-way ANOVA (drug $\times$ dose $\times$ time), followed by Tukey's post hoc comparisons.

5.3.4. Tail-flick test. ${ }^{21}$ The tail of each mouse was exposed to a focused beam of light and the latency to remove the tail from the path of the stimulus was recorded electronically using a photoelectric cell. The stimulus intensity was adjusted to produce baseline latencies of 3-4 s.

5.3.5. Hot plate test. ${ }^{22}$ Each mouse was placed on a hot plate $\left(54 \pm 1^{\circ} \mathrm{C}\right)$ and the latency to lick the hind paw was recorded. Mice not responding after $30 \mathrm{~s}$ were removed and assigned a latency of $30 \mathrm{~s}$. All the experiments were performed in 'blind' fashion. $\mathrm{ED}_{50}$ values were determined using nonlinear regression analyses.

5.3.6. Carrageenan-induced paw edema. ${ }^{24}$ Under halothane anesthesia male CD-1 mice were injected with lambda-carrageenan $(50 \mu \mathrm{L}, 1 \%$ in saline; Sigma) via the plantar surface of one hind paw 30 min after drug administration. Inflammation (paw volume: model 520 paw volume meter; IITC Life Sciences, Inc., Woodland Hills, CA.) was measured before and $4 \mathrm{~h}$ after injection of carrageenan. Indomethacin $(30 \mathrm{mg} / \mathrm{kg}$, po), a known anti-inflammatory, was used as a 'positive control.'

5.3.7. Glutathione depletion. ${ }^{29}$ Male CD-1 mice (20-30 g; Charles River Breeding Laboratories, Wilmington, MA) were treated with $6 \mathrm{mmol} / \mathrm{kg}$ 5a or APAP, or vehicle as described above (in a pilot study, $6 \mathrm{mmol} / \mathrm{kg}$ was established as the $\mathrm{LD}_{50}$ for APAP). Three hours after drug administration, mice from different treatment groups were killed and the livers perfused with heparinized saline. The right hemisphere was dissected and homogenized using a Teflon pestle in MPA $(5 \% \mathrm{w} / \mathrm{v})$ to a concentration of $5 \%$ $(w / v)$. Kidneys also were removed and homogenized with MPA $(5 \% \mathrm{w} / \mathrm{v})$ to a concentration of $10 \%(\mathrm{w} / \mathrm{v})$. The homogenates were centrifuged for $10 \mathrm{~min}$ at $3000 \mathrm{~g}$ at $4{ }^{\circ} \mathrm{C}$, and glutathione levels were measured in $300-\mu \mathrm{L}$ aliquots of the supernatant using a colorimetric assay kit (Calbiochem, La Jolla, CA).

\subsubsection{Serum transaminase activity. ${ }^{19,25}$ Twenty-four} hours after drug treatment, mice were decapitated and blood withdrawn into 1-cc heparinized syringes. Plasma was obtained by centrifugation of blood samples at $3000 \mathrm{rpm}$ for $10 \mathrm{~min}$ at $4{ }^{\circ} \mathrm{C}$. The plasma glutamicpyruvic transaminase (GPT) and glutamic-oxaloacetic transaminase (GOT) levels were determined by a Spectrophotometric test kit (Sigma). Mortality rate was recorded $24 \mathrm{~h}$ after drug administration.

5.3.9. HEPG-2 cells and human hepatocytes. HEPG-2 cells were grown and maintained in EMEM containing
NEAA (non-essential amino acids), supplemented with $10 \%$ fetal bovine serum (FBS), and incubated at $37^{\circ} \mathrm{C}$ with a constant supply of $5 \% \mathrm{CO}_{2}$. Primary human liver cells were grown in HCM (Clonetics, Walkersville, MD), and maintained in HMM (Clonetics, Walkersville, MD) at $37{ }^{\circ} \mathrm{C}$ with $5 \% \mathrm{CO}_{2}$. Cultures $(80 \%$ confluent) of HEPG-2 and primary hepatocytes growing in 6- and 24-well plates, respectively, were held $6-8 \mathrm{~h}$ in serumfree medium (EMEM, 0.5\% FBS for HEPG-2, and HMM for primary hepatocytes) before the addition of analgesics. The serum-starved cells were treated with 5a, APAP, or a nitrate ester derivative of acetaminophen (NO-APAP) for $6-8 \mathrm{~h}$ at $37^{\circ} \mathrm{C}$.

5.3.10. Hoechst staining for detection of apoptosis. Spent medium was removed from the experimentally treated cells, which were washed with $2 \mathrm{~mL}$ PBS (room temperature). Hoechst solution $(2 \mathrm{~mL}, 2 \mu \mathrm{M}$ final concentration) was added to the cells, and they were incubated at $37^{\circ} \mathrm{C}$ for $45 \mathrm{~min}$. Apoptotic cell death was detected by confocal microscopy under fluorescence illumination.

5.3.11. Western-blot analysis. The up-regulation of Fasligand (Fas-L) and activation of CAR (constitutive androstane receptor) were analyzed by Western blot. Briefly, the cell extracts were made and adjusted for protein concentrations by Bio-Rad method. About 15-20 $\mu \mathrm{g}$ protein was loaded onto an $8-16 \%$ gel (Invitrogen, Carlsbad, CA.), and electrophoresis was conducted for $2 \mathrm{~h}$ at $125 \mathrm{~V}$. The proteins were transferred onto nitrocellulose membrane at $30 \mathrm{~V}$ for $60 \mathrm{~min}$ at $4{ }^{\circ} \mathrm{C}$. The membranes were probed with either Fas-L- or CAR (human)-specific antibodies (Santa Cruz Biotechnology, Santa Cruz, CA) and phosphorylation of the Fas-L and CAR was detected by ECL kit. Quantitation of Fas-L and CAR proteins was performed by densitometry.

5.3.12. Determination of metabolites. Two-month-old CD-1 mice were fasted overnight. Next morning, following light halothane anesthesia, they were given po 5a, $3 \mathrm{mmol} / \mathrm{kg}$ in Tween 20 (vehicle). They were placed in Nalgene metabolic cages (two mice per cage) with water ad libitum. Food was supplied $6 \mathrm{~h}$ post dose treatment. The urine was collected in a plastic container, which was maintained in ice during the $24-\mathrm{h}$ collecting period. It was stored at $-20^{\circ} \mathrm{C}$ until use. At the time of the HPLC injection, aliquots were centrifuged in a microfuge at $6000 \mathrm{rpm}, 15^{\circ} \mathrm{C}$ for $10 \mathrm{~min}$, filtered with nylon filters $(0.45 \mu \mathrm{m})$, and used immediately or lyophilized.

In the HPLC-MS analysis, a volume of $20 \mu \mathrm{L}$ was injected. When lyophilized samples were used, they were dissolved in a mixture of acetonitrile- $0.1 \%$ ammonium acetate solution, $\mathrm{pH} 7$ (50:50, v/v). The HPLC-MS analyses were performed in an Agilent 1100 apparatus. The analytical column was a Luna $150 \times 4.6 \mathrm{~mm}, \mathrm{C} 18$ $(5 \mu \mathrm{m})$ Phenomenex column. The mobile phase was degassed automatically by the electronic degasser system. Before the analysis, the column was equilibrated and a gradient program was used for analysis of samples. The flow rate was maintained at $1.5 \mathrm{~mL} / \mathrm{min}$ and the column was maintained at $45^{\circ} \mathrm{C}$. The linear gradient mobile 
phase was $85 \%$ ammonium acetate buffer $(0.1 \%, \mathrm{pH} 3.6)$ and $15 \%$ acetonitrile at $0 \mathrm{~min} ; 10 \%$ ammonium acetate buffer ( $\mathrm{pH} \mathrm{3.6)}$ and $90 \%$ acetonitrile at $17 \mathrm{~min}$. When a UV detector was used, the wavelength of detection was set at 280, 254, and $210 \mathrm{~nm}$. Peak width, response time, and slit were set at $>0.03 \mathrm{~min}, 0.5 \mathrm{~s}$, and $8 \mathrm{~nm}$, respectively. In the MS detector, the capillary voltage was $\pm 2500 \mathrm{~V}$, the drying gas temp was $350^{\circ} \mathrm{C}$, the nebulizer pressure was $30 \mathrm{psig}$, drying gas flow was $12 \mathrm{~L} / \mathrm{min}$, and the fragmentor was at $70 \mathrm{eV}$, with a mass range of 150-800 amu.

\section{Acknowledgments}

This research was supported by the Neurobiotechnology Program of Louisiana and award number MDA972-03C-010 from the Defense Advanced Research Programs Agency (DARPA) Bio-Magnetics Interfacing Concepts. We thank Belen Gómez for technical assistance.

\section{References and notes}

1. Prescott, L. F. Am. J. Ther. 2000, 7, 143.

2. Boutaud, O.; Aronoff, D. M.; Richardson, J. H.; Marnett, L. J.; Oates, J. A. Proc. Natl. Acad. Sci. U.S.A. 2002, 99, 7130 .

3. Ouellet, M.; Percival, M. D. Arch. Biochem. Biophys. 2001, 387, 273.

4. Bjorkman, R. Acta. Anaesthesiol. Scand. Suppl. 1995, 103, 1 .

5. Pelissier, T.; Alloui, A.; Caussade, F.; Dubray, C.; Cloarec, A.; Lavarenne, J.; Eschalier, A. J. Pharmacol. Exp. Ther. 1996, 278, 8.

6. Pini, L. A.; Vitale, G.; Ottani, A.; Sandrini, M. J. Pharmacol. Exp. Ther. 1997, 280, 934.

7. Högestätt, E. D.; Jönsson, B. A. G.; Ermund, A.; Andersson, D. A.; Björk, H.; Basbaum, A. I.; Cravatt, B. F.; Zygmunt, P. M. J. Biol. Chem. 2005, 280, 31405.

8. Watkins, P. B.; Kaplowitz, N.; Slattery, J. T.; Colonese, C. R.; Colucci, S. V.; Stewart, P. W.; Harris, S. C. J. Amer. Med. Assoc. 2006, 296, 87.
9. Slattery, J. T.; Nelson, S. D.; Thummel, K. E. Clin. Pharmacol. Ther. 1996, 60, 241.

10. McGoldrick, M. D.; Bailie, G. R. Ann. Pharmacother. 1997, 31, 221.

11. James, L. P.; Mayeux, P. R.; Hinson, J. A. Drug. Metabol. Dispos. 2003, 31, 1499.

12. Bessems, J. G.; Vermeulen, N. P. Crit. Rev. Toxicol. 2001, $31,55$.

13. Fiorucci, S.; Antonelli, E.; Mencarelli, A.; Palazzetti, B.; Alvarez-Miller, L.; Muscara, M.; del Soldato, P.; Sanpaolo, L.; Wallace, J. L.; Morelli, A. Br. J. Pharmacol. 2002, 135, 589.

14. Zhang, J.; Huang, W.; Chua, S. S.; Wei, P.; Moore, D. D. Science 2002, 298, 422.

15. Bazan, N. G.; Alvarez-Builla, J., U.S. Patent 5,554,636, 1996.

16. Bazan, N. G.; Alvarez-Builla, J., U.S. Patent 5,621,110, 1997.

17. Gonzalez-Martin, G.; Lyndon, C.; Sunkel, C. Eur. J. Pharm. Biopharm. 1998, 46, 293.

18. Koster, R.; Anderson, M.; de Beer, E. J. Fed. Proc. 1959 , 18,412 .

19. Young, D. S.; Pestaner, L. C.; Gibberman, V. Clin. Chem. 1975, 21, 1D.

20. Dubuisson, D.; Dennis, S. G. Pain 1977, 4, 161.

21. D'Amour, F. E.; Smith, D. J. Pharmacol. Exp. Ther. 1941, $72,74$.

22. Woolfe, G.; MacDonald, A. D. J. Pharmacol. Exp. Ther. 1944, 80, 300 .

23. Levy, L. Life Sci. 1969, 8, 601.

24. Assi, A. Pharmacol. Res. 2001, 43, 521.

25. Amador, E.; Wacker, W. Clin. Chem. 1962, 8, 343.

26. Al-Swayeh, O. A.; Futter, L. E.; Clifford, R. H.; Moore, P. K. Br. J. Pharmacol. 2000, 130, 1453.

27. Mukherjee, P. K.; Marcheselli, V. L.; Serhan, C. N.; Bazan, N. G. Proc. Natl. Acad. Sci. U.S.A. 2004, 101, 8491.

28. Mattson, M. P.; Bazan, N. G. In Basic Neurochemistry: Molecular, Cellular and Medical Aspects; Siegel, G., Albers, R., Brady, S., Eds.; Elsevier Academic Press, 2006; pp 603-615.

29. Anderson, M. E.. In Glutathione: Chemical, Biochemical and Medical Aspects; Dolphin, D., Poulson, R., Avramovic, O., Eds.; John Wiley and Sons, 1989; Vol. A, pp 339365. 